\title{
The Relationship Between Obesity and a Decrease in the Range of Motion of the Pelvic Joint
}

\author{
(Faculty of Medicine, Jenderal Achmad Yani University)
}

\author{
Indarti Tri Murtini \\ Department of Anatomy, Faculty of Medicine \\ Jenderal Achmad Yani University \\ Cimahi, Indonesia
}

\author{
Apen Apgani* \\ Department of Physiology, Faculty of Medicine \\ Jenderal Achmad Yani University \\ Cimahi, Indonesia \\ *apen.afgani@fk.unjani.ac.id
}

\author{
Disya Fariha Dimyati, Fahmi Nur Hidayatullah \\ Faculty of Medicine \\ Jenderal Achmad Yani University \\ Cimahi, Indonesia \\ fahminhdr@gmail.com
}

\begin{abstract}
Obesity is a health problem in Indonesia. Data shown by Basic Health Research (Riskesdas) in 2013 described the prevalence of obesity in Indonesia as increasing annually. Obesity becomes a risk factor for many diseases, the example of it is a musculoskeletal disorder in the cause of mobility disorder. Victims of obesity are known to have limited movement and joint range of motion (ROM) reduction caused by mechanical hindrance in joint movement. This research is focusing on discovering the relationship between obesity and hip joint ROM reduction in students at the Faculty of Medicine Jenderal Achmad Yani University. This research is also using a correlation analytical layout with a cross-sectional approach. The research subject is consisting of 20 males and 38 females student members with a body mass index (BMI) of $\geq 25 \mathrm{~kg} / \mathrm{m} 2$. Anthropometrical data and hip joint ROM are obtained from direct measurement of the subject. The data are descriptively analyzed then continued with Spearman correlation assessment. The result of this research is stating that there is a significant negative correlation between obesity and hip joint ROM flexion, extension, abduction, adduction, and exorotation ( 1 < 0.05 ), except for hip joint ROM abduction in female $(p>0.05)$ also a significant positive correlation between obesity and hip joint ROM endorotation ( $p$ $0.05)$. In conclusion, this research is showing that there are relations between obesity and hip joint ROM reduction in flexion, extension, abduction, adduction, and exorotation movements. Therefore, in a female group, there is no relation between obesity and hip joint ROM reduction in adduction.
\end{abstract}

Keywords—obesity, range of motion, hip joint

\section{INTRODUCTION}

Obesity is a public health problem around the world. The World Health Organization (WHO) declared that in 2016, 39\% of adults in the world over the age of 18 are overweight and $13 \%$ are obese. The prevalence of obesity is not only increasing in developed countries but also in developing countries including Indonesia. According to the 2013 Basic Health Research (Riskesdas) data, the prevalence of obesity in Indonesia is relatively high, as much as $19.7 \%$ in men over 18 years of age and $32.9 \%$ in women over 18 years. In the obesity problem in West Java in 2016, there were as many as 138,965 people. The prevalence of obesity in medical faculty students is higher in males than females concerning physical activity and diet. The increasing prevalence of obesity shows that obesity in Indonesia will become a new problem that needs serious attention [1-5].

Obesity occurs because of an imbalance between food intake and physical activity. Measurement of body mass index (BMI), a simple measure of body weight, is often used to classify overweight and obesity in adults. The results of BMI measurement $\geq 25 \mathrm{~kg} / \mathrm{m} 2$, included in the classification of obesity. Obesity can increase risk factors for several diseases such as hypertension, heart disease, diabetes mellitus, musculoskeletal disorders, mobility disorders, and even psychiatric disorders. Musculoskeletal disorders that occur in obese sufferers are caused by various kinetics and kinematics disorders. Obese people are reported to have functional limitations in carrying out their daily activities, especially those requiring high flexibility. Several studies have stated that the prevalence of musculoskeletal disorders in obese patients generally occurs in the lower limb regions [6-8].

Obesity is characterized by the accumulation of excess body fat in adipose tissue, including around the joints. Also, if you have arthritis, the role of pro-inflammatory adipokines 
derived from adipose tissue can aggravate the disease. This results in motion limitations resulting in mechanical resistance in joint movement. Obese people also tend to have low physical activity and sit more so that their muscle strength is low. This can cause a change in the range of motion (ROM) value in the joint [8-12].

Range of motion (ROM) is the quantity of motion distance when the joint is fully moved. ROM can be measured with a goniometry instrument that is measured in angles. The normal ROM value is very important to know because it provides a standard to determine the balance between mobility and stability. The value of ROM describes the flexibility of a joint. The greater the ROM value of a joint, the lower the chance of injury to the joint. The ROM value is affected by age, the ROM value is determined based on age levels, the older the ROM value will decrease. Also, gender can affect the ROM value. In women, the ROM value is greater than men, this is related to hormonal factors and differences in the anatomy of the hip joint [13-15].

The hip joint is one of the joints of the inferior limb. The hip joint plays an important role in supporting the human body, standing, and walking. The hip joint consists of the head of the femoris and the acetabulum of the pelvis. The movement in this joint consists of 3 pairs of movements, namely flexionextension, abduction-adduction, and endorotation-exorotation $[13,14]$.

In Joao et al's study, it was reported that there was a significant correlation between BMI with flexion and hip joint adduction which indicated a decrease in ROM values for hip joint flexion and adduction in obese subjects. Various movements of the hip joint are needed in everyday life, therefore a decrease in the ROM value of the hip joint will cause a decrease in mobility function. If the hip joint ROM is reduced, it will experience difficulty in carrying out daily activities such as walking, going up and downstairs, going up and down the car, sitting, standing, affecting gait and balance. This can increase the risk of falling and fracturing. About $10 \%$ of adults are obese, have serious injuries such as fractures, head injuries, and joint dislocations [11,15-19].

Based on the explanation above, it is known that one of the factors that influence the decline in ROM value is obesity. The medical school student schedule is busy, allowing students not to have time to exercise. Also, students tend to consume more foods high in fat and carbohydrates than fruits and vegetables. So that there may be an imbalance between energy intake and energy expended $[4,5]$. Therefore, the authors are interested in researching the relationship between obesity and range of motion (ROM) of the hip joint in students of the Faculty of Medicine, General Achmad Yani University.

\section{METHODS}

The design of this study is an observational study with a cross-sectional approach that uses correlation analytic methods to see the strength of the relationship between one variable and another.
The subjects in this study were students of Faculty of Medicine Jenderal Achmad Yani University class 2018-2015, who met the inclusion and exclusion criteria for the study. The study inclusion criteria were students with a BMI $\geq 25 \mathrm{~kg} / \mathrm{m}^{2}$ (obesity) with low physical activity and willing to be the subject of research. The study exclusion criteria were students with a history of local and systemic joint disease, fractures around the hip and knee, a history of neuromuscular disease, and muscle atrophy.

This study started from the preparation of research subjects, preparation of tools and materials, BMI examination, and ROM measurements of flexion, extension, abduction, adduction, endorotation, and exorotation of the hip joint. The preparation of research subjects started from collecting data from all Faculty of Medicine, Jenderal Achmad Yani University students by filling out a data form containing identity, weight, height, BMI, and a questionnaire. After obtaining the measurement results, then selecting subjects who meet the study inclusion criteria is carried out. Research subjects will get an explanation of the research objectives, research procedures, the inconvenience that will arise, and then will be asked for approval to participate in the research and sign a statement of approval. The examination starts with the BMI examination which consists of measuring body weight, height, and calculating BMI. After confirming the BMI $\geq 25 \mathrm{~kg} / \mathrm{m}^{2}$ (obesity), then continued with ROM measurements of flexion, extension, abduction, adduction, endorotation, and exorotation of the hip joint. The results of the examination and measurement are then recorded on the research form.

\section{RESULTS AND DISCUSSION}

\section{A. Age Characteristics}

Characteristics of age in the study can be seen in table 1 . Age can affect the value of the range of motion (ROM) of the hip joint, the older the ROM value decreases. This is related to a sedentary lifestyle and degenerative processes. ROM values are determined based on the age range. In this study, the age range of student respondents at the Faculty of Medicine Unjani was between 17-22 years, so that the age characteristics of the respondents were similar $[10,14]$.

TABLE I. AGE CHARACTERISTICS

\begin{tabular}{|l|l|l|l|l|}
\hline \multirow{2}{*}{ Age } & \multicolumn{2}{|c|}{ Total } & \multicolumn{2}{c|}{ Percentage } \\
\cline { 2 - 5 } & Male & Female & Male & Female \\
\hline 17 & 1 & 2 & 5 & 5,3 \\
\hline 18 & 7 & 6 & 35 & 15,8 \\
\hline 19 & 6 & 8 & 30 & 21,1 \\
\hline 20 & 4 & 13 & 20 & 34,2 \\
\hline 21 & 2 & 8 & 10 & 21,1 \\
\hline 22 & 0 & 1 & 0 & 2,6 \\
\hline Total & 20 & 38 & 100 & 100 \\
\hline
\end{tabular}

Based on the age characteristics in this study, the most male respondents were at the age of 18 years, namely 7 people $(35 \%)$, the youngest age (17 years) as many as 1 person, and 
the oldest age (21 years) as many as 2 people. Most of the female respondents were at the age of 20, namely as many as 13 people $(34.2 \%)$, the youngest age (17 years) as many as 2 people, and the oldest age ( 22 years) as many as 1 people.

\section{B. Antropometri and BMI Characteristics}

Analysis of body weight, height, and body mass index of the respondents in this study can be seen in Table 2 . The average body weight of male respondents was greater than that of female respondents, namely $92.65 \mathrm{~kg}$ with a standard deviation of $17.43 \mathrm{~kg}$ and a median of $92 \mathrm{~kg}$. The average body weight of female respondents was $75.05 \mathrm{~kg}$ with a standard deviation of $11.44 \mathrm{~kg}$ and a median of $73.50 \mathrm{~kg}$.

The average height of the male respondents was greater than the female respondents, namely $167.90 \mathrm{~cm}$ with a standard deviation of $6.34 \mathrm{~cm}$ and a median of $169.25 \mathrm{~cm}$. The average height of the female respondents was $156.04 \mathrm{~cm}$ with a standard deviation of $4.86 \mathrm{~cm}$ and a median of $156 \mathrm{~cm}$.

The average body mass index in this study belongs to the second classification of obesity, namely $\geq 30 \mathrm{~kg} / \mathrm{m}^{2}$. The body mass index (BMI) of male respondents had a greater average than female respondents, namely $33.10 \mathrm{~kg} / \mathrm{m}^{2}$ with a standard deviation of $5.17 \mathrm{~kg} / \mathrm{m} 2$ and a median of $32 \mathrm{~kg} / \mathrm{m}^{2}$. The average BMI of female respondents was $30.93 \mathrm{~kg} / \mathrm{m}^{2}$ with a standard deviation of $3.84 \mathrm{~kg} / \mathrm{m}^{2}$ and a median of $30.55 \mathrm{~kg} / \mathrm{m}^{2}$.

TABLE II. ANTROPOMETRI AND BMI CHARACTERISTICS

\begin{tabular}{|l|l|l|l|l|}
\hline \multirow{2}{*}{ Variables } & \multicolumn{2}{|c|}{ Median } & \multicolumn{2}{c|}{ Mean (SD) } \\
\cline { 2 - 5 } & \multicolumn{1}{|c|}{ Male } & \multicolumn{1}{|c|}{ Female } & \multicolumn{1}{c|}{ Male } & Female \\
\hline Weight & 92,00 & 73,50 & 92,65 & 75,05 \\
\hline Height & 169,25 & 156,00 & 167,90 & 156,04 \\
\hline BMI & 32,00 & 30,55 & 33,10 & 30,93 \\
\hline
\end{tabular}

The results of this study are following the research of Ranggadwipa in 2014 and Sahin et al. in 2015 which explained that the prevalence of obesity in male medical faculty students was higher than that of women. The results of this study are following the research of Ranggadwipa in 2014 and Sahin et al. in 2015 which explained that the prevalence of obesity in male medical faculty students was higher than that of women. The habit of consuming foods high in fat and carbohydrates with light physical activity causes medical faculty students to be obese. Environmental and cultural factors play a role in the occurrence of obesity in students. Universities located in urban areas tend to provide less healthy food than fast food, in addition to the sedentary lifestyle of students who prefer to use vehicles rather than walk $[4,5]$

\section{Range of Motion (ROM) Overview of the Pelvic Joint}

An overview of the range of motion (ROM) of hip joint movement in obese students of the Faculty of Medicine, General Achmad Yani University can be seen in Table 3.
TABLE III. RANGe OF Motion (ROM) OVERVIEW OF THE PELVIC JoINT

\begin{tabular}{|l|l|l|l|l|}
\hline \multirow{2}{*}{\multicolumn{1}{|c|}{ Variables }} & \multicolumn{2}{c|}{ Median } & \multicolumn{2}{c|}{ Mean } \\
\cline { 2 - 5 } & \multicolumn{1}{c|}{ Male } & Female & Male & Female \\
\hline Right Flexion & 86 & 90 & 83,90 & 90,76 \\
\hline Left Flexion & 89 & 90 & 84,35 & 91,34 \\
\hline Right Extension & 10 & 10 & 10,40 & 11,37 \\
\hline Left Extension & 10 & 10 & 9,85 & 11,18 \\
\hline Right Abduction & 30 & 30 & 31 & 30,11 \\
\hline Left Abduction & 29,50 & 30 & 31,45 & 31,03 \\
\hline Right Adduction & 18 & 18 & 16,75 & 17,84 \\
\hline Left Adduction & 18 & 18 & 16,70 & 17,26 \\
\hline Right Endorotation & 40 & 35 & 38 & 35,89 \\
\hline Left Endorotation & 40 & 33 & 38,05 & 34,03 \\
\hline Right Exorotation & 30 & 28,50 & 32,30 & 27,66 \\
\hline Left Exorotation & 30,50 & 28 & 31,20 & 27,29 \\
\hline
\end{tabular}

The results of the analysis showed that the mean ROM of flexion, extension, abduction, adduction, and exorotation of the hip joint decreased and the ROM increased in endorotation movements. The mean ROM of flexion, extension, abduction, and adduction movements was greater in female respondents, while the mean ROM of hip joint endorotation and exorotation movements was greater in male respondents.

This result is following the research of Chung et al. in 2009 in Thailand and Dehghan et al. in 2014 in Malaysia which stated that women tend to have greater ROM than men. In general, women have greater ROM than men. This is due to hormonal factors related to the type of muscle fibers. Testosterone in men can trigger an increase in muscle size and mass with fibers that tend to provide muscle strength and endurance, while in women there is the hormone estrogen which can make muscles more flexible because the muscle fibers are more able to stretch and recover quickly. Differences in hip anatomy in males and females also affect the ROM of the hip joint [20,21].

Another study stated that the percentage of upper limb fat distribution in women is greater than that of men with the same BMI so that the mechanical resistance of the hip joint in obese women is higher. This can lead to a greater decrease in hip joint ROM in women with the same BMI. In this study, it can be seen that the average body mass index in men is greater than in women so that the hip joint ROM in men decreases more [22].

TABLE IV. TEST FOR DIFFERENT RANGES OF MOTION (ROM) OF THE RIGHT AND LEFT HIP JOINTS

\begin{tabular}{|c|c|c|}
\hline \multirow{2}{*}{ Variables } & \multicolumn{2}{|c|}{ P-value } \\
\hline & Male & Female \\
\hline Hip Joint Flexion & 0.544 & 0,719 \\
\hline Hip Joint Extension & 0,218 & 0,854 \\
\hline Hip Joint Abduction & 0,492 & 0,086 \\
\hline Hip Joint Adduction & 0,455 & 0,306 \\
\hline Hip Joint Endorotation & 0,686 & 0,741 \\
\hline Hip Joint Exorotation & 0,104 & 0,429 \\
\hline
\end{tabular}

Based on Table 4, analysis of the Wilcoxon ROM difference test of the right and left hip joints, the results 
obtained are $\mathrm{p}>0.05$ in all hip joint movements, which means that there is no significant difference in right and left ROM so for the next analysis the researcher chose the right hip joint ROM.

\section{Relationship between Obesity and Decreased Range of Motion (ROM) of the Pelvic Joint}

The relationship between BMI obesity $\left(\geq 25 \mathrm{~kg} / \mathrm{m}^{2}\right)$ and hip joint ROM can be seen based on the results of the analysis from the Spearman Correlation Test with a 95\% degree of confidence in Table 5.

TABLE V. THE ASSOCIATION OF OBESITY WITH HIP JOINT RANGE OF MOTION (ROM)

\begin{tabular}{|c|l|c|c|c|c|c|c|}
\hline \multicolumn{2}{|c|}{} & HF & HE & HAb & HAd & Hen & Hex \\
\hline Male & $\begin{array}{l}\text { P- } \\
\text { Value }\end{array}$ & 0,000 & 0,013 & 0,000 & 0,001 & 0,003 & 0,016 \\
\hline Female & $\begin{array}{l}\text { P- } \\
\text { Value }\end{array}$ & 0,004 & 0,028 & 0,115 & 0,007 & 0,000 & 0,015 \\
\hline
\end{tabular}

HF: Hip Flexion; HE: Hip Extension; HAb: Hip Abduction; HAd: Hip Adduction; Hen: Hip Endorotation; Hex: Hip Exorotation.

The analysis showed that there was a significant relationship between BMI obesity and ROM flexion, extension, abduction, adduction, endorotation and hip joint exorotation. A significant relationship can be seen from the $p$ value $\leq 0.05$. Meanwhile, the relationship between BMI obesity and hip joint abduction ROM in the female respondent group did not have a significant relationship. This is influenced by hormonal factors in women that affect the flexibility of the abductor muscle group, so that the statistical test does not show a significant relationship.

The association between BMI obesity and ROM flexion, extension, abduction, adduction, and exorotation of the hip joint showed a negative correlation in male and female respondents. A significant negative correlation was observed between BMI obesity with ROM of hip joint flexion and adduction with very strong relationship strength in male respondents and moderate strength in female respondents. The negative correlation shows that the higher the BMI, the lower the ROM value of hip joint flexion, extension, abduction, adduction, and exorotation.

The association between BMI density and ROM hip joint endorotation showed a significant positive correlation with a strong relationship between male and female respondents. The positive correlation shows that the higher the BMI, the greater the ROM value of hip joint endorotation.

The results of this study are consistent with research conducted by Joao et al. 2014 in Brazil in children aged 6-12 years, there is a significant negative correlation between obesity and ROM flexion and hip joint adduction. The results of this study are also following the study of Koley et al. 2014 in India in obese individuals there is a significant positive correlation between ROM endorotation of the hip joint and body weight $[8,11]$.
In obese individuals, the decrease in ROM is affected by the presence of excess fat tissue around the joint segment which can mechanically inhibit joint movement. Obesity factors associated with other factors such as excess joint load, posture changes, and a sedentary lifestyle can affect musculoskeletal development and result in decreased ROM [8$12]$.

ROM measurement in this study was carried out actively, which is expected to provide better results for assessing joint motion. Synovial joint flexibility is determined by various factors such as the shape of the articular surface, joint capsule, ligaments, and soft tissue around the joint. However, to understand changes in mobility, it can be more focused on postural changes in obese individuals. Changes such as genu valgus and pelvic endorotation are caused by excess fat in the upper leg so that the lower leg tends to move away and there is increased endorotation of the pelvis and overpressure of the lateral compartment of the knee. According to research by de Souza et al., It was proven that $50 \%$ of obese sufferers have a pathological disorder, namely genu valgus, with an intermalleolar distance greater than $10 \mathrm{~cm}$ [23]

Genu valgus posture and pelvic endorotation with consequent hip adduction will tend to cause joint instability. Obese individuals also tend to have low physical activity, which can lead to joint instability, associated with a decrease in muscle strength and tensile strength. Physical activity can lead to hypertrophy of ligaments and connective tissue, resulting in increased muscle strength, improved proprioceptively, and developing protective reflexes with consequently increased joint stability. Decreased activity and muscle strength can affect the proper adaptation of the muscles, causing unstable joint movement. This can affect gait and balance, increasing risk factors for falls and fractures [23].

\section{CONCLUSION}

The average BMI of obese students at the Faculty of Medicine, Jenderal Achmad Yani University, was greater in the male group than female and was classified as obesity II.

The average hip joint ROM in obese male and female students at the Faculty of Medicine, Jenderal Achmad Yani University experienced a decrease in flexion, extension, abduction, and adduction and exorotation, as well as an increase in endorotation movements.

There is a significant relationship between BMI obesity with ROM flexion, extension, abduction, adduction, endorotation, and exorotation of the hip joint. Meanwhile, the relationship between BMI obesity and hip joint abduction $\mathrm{ROM}$ in the female respondent group did not have a significant relationship.

Based on the results of the above research, the researchers suggest that further research using dual X-ray absorption (DXA) is needed. Further research is needed by measuring the intermalleolar distance so that changes in posture in research subjects can be identified. Then it is necessary to provide 
information to students of the Faculty of Medicine, General Achmad Yani University that regulating adequate food intake and physical activity can maintain a normal BMI and prevent musculoskeletal disorders due to limited mobility.

\section{REFERENCES}

[1] World Health Organization, "Overweight and obesity," 2016. [Online]. Retrieved from: http://www.who.int/mediacentre/factsheets/ [Accessed on: 7 June 2018].

[2] Badan Penelitian dan Pengembangan Kesehatan Kementrian Republik Indonesia, "Riset kesehatan dasar," 2013. [Online]. Retrieved from: http://www.depkes.go.id/ http://www.who.int/mediacentre/factsheets/ [Accessed on: 7 June 2018]

[3] Dinas Kesehatan Provinsi Jawa Barat, "Profil kesehatan," 2016. [Online]. Retrieved from: http://ww.dinkes.go,id/ [Accessed on: 7 June 2018].

[4] A. Sahin, M. Aykut, and O. Ahmad, "Obesity Prevalence and Related Factors among Medical Students in Kayseri," Eryces Medical Journal, vol. 37, no. (2), pp.51-58, 2015.

[5] Ranggadwipa, D.D. Hubungan Aktivitas Fisik dan Asupan Energi Terhadap Massa Lemak Tubuh dan Lingkar Pinggang pada Mahasiswa Fakultas Kedokteran Universitas Diponegoro. Semarang: Fakultas Kedokteran Universitas Diponegoro, 2014, pp. 5-18.

[6] Perhimpunan Dokter Spesialis Penyakit Dalam Indonesia, "Obesitas," In A.W. Sudoyo, B. Setiyohadi, L. Alwi, M. Simadibrata, S. Setiati, editors. Buku ajar ilmu penyakit dalam, Edisi 6. Jakarta: Interna Publishing, 2014, pp. 2561-6.

[7] K.B. Schelbert, "Comorbidities of obesity," Primary Care, vol. 36, no. (2), pp. 271- 85, 2016.

[8] S. Koley and J.K. Sodhi, "Correlations of hip and knee range of motion with selected anthropometric variables in Indian obese individuals," Annalis of Biological Research, vol. 5, no. (2), pp. 47-50, 2014.

[9] W. Park, J. Ramachandran, P. Weisman, and E.S. Jung, "Obesity effect on male active joint range of motion," Ergonomics, vol. 53, no. (1), pp. 102-108, 2010.

[10] U.E. Larsson and E. Mattsson, "Functional limitations linked to high body mass index, age and current pain in obese women," International Journal of Obese,vol. 25, no. (6), pp. 893-899, 2001.
[11] S.M.A. Joao, M.N. Nizhizaki, H.C. Yamamoto, V.L.C. Barbosa, and J.F. Sauer, "Obesity effect on children hip and knee range of motion," International Journal of Obese, vol. 05, no. (09), pp. 490-497, 2014.

[12] S.N. Jannini, U. Doria, D. Damiani, and C.A.A. Silva, "Musculoskeletal pain in obese adolescents," Journal Pediatric, vol. 87, no. (4), pp. 329335, 2011.

[13] P.K. Levangie and C.C. Norkin, Joint structure and function Philadelphia: F.A Davis Company, 2005, pp. 166-70, 356-78.

[14] R.L. Drake, A.W. Volg, dan A.W.M. Mitchell, Gray dasar-dasar anatomi. Alih bahasa: Viskasari Pintoko Kalanjati. Singapore: Elsevier Churchil Livingstone, 2012, pp. 20-32, 165-74.

[15] J. Hamill and K.M. Kutzen, Biomechanical basis of human movement, 2 nd ed. Philadelphia Baltimore New York London Buenos Aires Hong Kong Sydney Tokyo: Lippincoot Williams \& Wilkins, 2006, pp. 116, 207-21.

[16] D.A. Neumann, Kinesiology of the musculoskeletal system, 2 nd ed. ST Louis, United States: Elsevier Helath Science, 2010, pp. 289-92, 394415.

[17] L.E. Holt and T.W. Pelham, Flexibility : a concise guide to conditioning, performance enhancement, injury prevention, and rehabilitation, 1 st ed. Totowa: Humana Press, 2008, pp. 8-10.

[18] A. Hemmerich, H. Brown, S. Smith, S.S.K. Marthandam, and U.P. Wyss, "Hip, knee and ankle kinematics of high range of motion activities of daily living," International Journal of Kinematics, vol. 4, pp.770-781, 2016

[19] C.M. Arnold and N.C. Gyurcsik, "Bone health risk factors for falls in older adults with lower extremity arthritis," A Conceptual Framework of Current Knowledge and Future Directions, vol. 64, no. (3), pp. 302-14, 2014.

[20] M.J. Chung and M.J.J. Wang, "The effect of age and gender on joint range of motion of worker population in Taiwan," Int J Ind Ergon, vol. 39, no. (4), pp. 596-600, 2012.

[21] J.B. Feland, J.W. Myrer, S.S. Schulthies, G.W. Fellingham, and G.W Measom, "The Effect of Duration of Stretching of the Hamstring Muscle Group for Increasing Range of Motion in People Aged 65 Years or Older," Phys Ther, vol. 81, no. (5), pp. 1100-17, 2010.

[22] J. Yamauchi, T. Kurihara, M. Yoshikawa, S. Taguchi, and T. Hashimoto, "Specific characterization of regional storage fat in upper and lower limbs of young healthy adults," Springerplus Journal, vol. 37, no. (2), pp. 402-12, 2015.

[23] S.A.F. De Souza, J. Faintuch, A.C. Valezi, A.F. Sant'Anna, J.J. GamaRodrigues, I.C. de Batista Fonseca, and R.D. de Melo, "Postural changes in morbidly obese patients," Obesity surgery, vol. 15, no. (7), pp. 10131016,2005 